$$
\begin{gathered}
\text { 수목장림 입지 평가기준 설정 연구 }{ }^{\dagger} \\
\text { 문창순*·이시영** }
\end{gathered}
$$

"배재대학교 대학원 원예조경학과 박사. "배재대학교 조경학과 교수

\title{
Development of Site Evaluation Criteria for Woodland Burial Grounds
}

\author{
Moon, Chang Soon ${ }^{*} \cdot$ Lee, ShiYoung ${ }^{*}$ \\ *Ph.D., Dept. of Horticulture \& Landscape Architecture, Graduate School of PaiChai University \\ **Professor, Dept. of Landscape Architecture, PaiChai University
}

\begin{abstract}
The demand for National Woodland Burial Grounds is expected to increase as interest in natural burial, including woodland burial, is increasing. This study was performed to provide evaluation criteria applying weighting factors to the evaluation for location selection. Through literature review, location selection evaluation factors for forest facilities, similar to forest welfare facilities, were reviewed and analyzed. As a result of the analysis, 74 preliminary evaluation criteria were selected. Based on the results, three expert groups (public servants in central and local governments and other public agencies in charge of forest welfare facility, related field researchers, and civil experts) reviewed the preliminary evaluation factors. Evaluation factors were classified into two categories, 6 sub-categories, and 22 segments. The selected evaluation factors were layered for the second preference survey. They were classified into Forest Environment and Human Environment, and those categories were further classified into three categories. Then they were further classified into segments. After segmentation, the experts who participated in the first survey checked the differences in the significance of the layered factors by utilizing AHP. The site evaluation criteria table was prepared using the evaluation criteria and the significance of each layer. In order to apply it to the candidate sites, 10 sites including the existing National Woodland Burial Grounds and 9 candidate sites considered in the previous studies were compared and analyzed including Ulju County Ulsan City, Suncheon City Jeollanam-do and Janggun-myeon Sejeong City.
\end{abstract}

Key Words: Forest Welfare Facility, Forest Welfare Service, Natural Burial Ground, A Feasibility Assessment

\section{국문초록}

수목장을 비롯한 자연장에 대한 관심이 증가됨에 따라 국립수목장림의 수요는 증가할 것으로 예상된다. 수목장림의 입지 선정을 위한 평가요소를 마련하고, 가중치 적용을 통해 수목장림 조성에 도움이 되는 입지 평가기준을 제시하고자 다음과 같이 연구를 진행하였다. 선행연구를 검토해 다른 산림복지시설과 유사한 산림시설, 기타 시설들에 대한 입지선정

\footnotetext{
${ }^{\dagger}$ : 이 논문은 2019년도 배재대학교 교내학술연구비 지원에 의하여 수행된 것임.

Corresponding author: ShiYoung Lee, Professor, Dept. of Landscape Architecture, PaiChai University, Daejeon 35345, Korea, Tel.: +82-42-520-5881, E-mail: sylee@pcu.ac.kr
} 
검토요소를 분석하여 74 개의 예비평가요인을 선정하였다. 이를 토대로 3 그룹의 전문가집단(국가 - 지자체 - 공공기관 산 림복지시설 담당자, 관련분야 연구자, 수목장림 민간 전문가)의 예비평가요인 검토를 거쳐 2 개 대분류, 6 개 중분류, 22 개 소분류의 평가요인을 선정하였다. 선정한 평가요인은 2 차 선호도 조사를 위해 계층화 하였다. 먼저 산림환경과 인문환경 으로 대분류하고, 각각 3 가지 항목으로 중분류 후에 다시 한 번 각각 소분류하여 1 차 조사에 참여한 전문가를 대상으로 $\mathrm{AHP}$ 를 활용해 계층화된 요인별 중요도 차이를 확인하였다. 평가요인을 활용하여 입지평가 기준표를 마련하고, 각 계층별 중요도를 적용하였다. 이를 후보지에 적용하기 위해 기존에 운영하고 있는 국립수목장림과 선행연구에서 국립수목장림 후보지로 검토하였던 9 개소 등 10 개소를 대상으로 평가하여 비교 분석하였다. 평가 결과, 울산 울주, 전남 순천, 세종 장군의 순으로 나타났다.

\section{주요어: 산림복지시설, 산립복지서비스, 자연장지, 타당성 평가}

\section{I. 서론}

사람의 한평생은 숲과 더불어 시작하고, 숲과 함께 생활하며, 숲 혹은 산과 더불어 생을 마감한다. 새 생명의 탄생과 더불어 매다는 금줄의 숯과 솔가지는 일생의 시작이 숲과 나무와 연 관을 맺고 있음을 보여주며, 모친과 생명을 함께 나누던 태를 묻는 공간도 역시 경관이 좋고 청정한 산이었다. 숲과 산에 기 대어 살다가 일생을 마무리하는 순간 저 세상의 또 다른 삶을 위한 작은 공간도 역시 칠성판 목재를 짊어지는 것으로 시작하 여 산으로 간다. 새로 태어나면서 태를 묻은 산에다가 일생을 살고 가는 한 몸을 다시 누이는 것이다(Korea Forest Welfare Institute: FOWI, 2018).

저출산, 고령화, 핵가족화로 인해 분묘관리가 어려워짐에 따라 매장에서 화장으로 장사문화가 변화하고 있으며, 고령자의 $28.2 \%$ 가 화장 후 자연장을 선호하는 만큼 자연장의 수요가 점 차 증가할 것으로 예상된다. 국립수목장림인 하늘숲추모원(48ha, 6,315본)을 기준으로 80 세 이상 잠재이용인구를 모두 수용한 다고 가정할 경우, 현재의 30 배가 더 조성되어야 할 것으로 예 상ㄱㄷ된다(Korea Forest Service: KFS, 2015a). 그러나 현행 법 령의 수목장림 시설기준은 면적, 표지, 안전 등 포괄적인 규정 만 존재하고, 조성을 위한 구체적인 시설규정의 부재로 $(\mathrm{KFS}$, 2014) 정치적 - 행정적 관점이 중요하게 고려되어 후보지 선정 에서 주민과의 갈등에 부딪히는 경우가 발생되고 있다(Moon and Lee, 2018).

다른 산림복지시설의 경우, 해당 시설의 지정 또는 조성계획 승인에 앞서 시·도지사 또는 관계분야 전문가와 함께 타당성 평갈를 통해 선정근거를 명확히 하고 있다. 그러나 수목장림 의 경우, 수목장림을 기피시설로 보는 시각이 존재함에도 이해 관계자에게 제시할 객관적인 적정입지 선정근거가 명확하지 않아서 조성에 어려움을 겪고 있는 실정이다.

따라서 이번 연구는 수목장림의 입지 선정을 위한 평가요소 를 마련하고, 가중치 적용을 통해 수목장림 조성에 도움이 되 는 입지 평가기준을 제시하는 것을 그 목적으로 한다.

\section{II. 이론적 고찰}

\section{1. 수목장림}

수목장림(樹木葬林)이란 r장사 등에 관한 법률」에서 r산림 자원의 조성 및 관리에 관한 법률」 제 2 조제 1 호에 따른 산림에 조성하는 자연장지라고 정의하고 있다.

수목장림을 비롯한 자연장과 관련해 Ministry of Health and Welfare(2007), KFS(2008), Ministry of Health, Welfare and Family Affairs(2009), Kim(2012a), KFS(2012), Kyon(2011), Woo(2013), Gwon(2014), KFS(2014), KFS(2015a), KFS(2015b), Park et al.(2015) 등의 연구가 진행되었으며, 관련 규정으로 r국유 수목장림 운영 관리에 관한 규정(산림청 고시 제2016-44 호) 이 있다.

수목장림은 「장사 등에 관한 법률」에 따라 조성하며, 조성 주체에 따라 공설묘지 등의 설치(제13조), 사설묘지의 설치 등 (제14조), 자연장지의 조성(제16조) 등 수목장림을 조성할 수 있는 근거에 따라 수목장림의 면적, 표지의 규격, 편의시설의 종류 및 설치기준 등을 준수하여야 하며, 조성 주체에 따라 특 별시장 - 특별자치도지사 - 시장 - 군수 - 구청장에게 신고(개인, 문중)하거나 허가(법인 등)를 받아야 한다(Moon et al., 2018).

제 17 조(묘지 등의 설치 제한)에 따라 자연장지를 설치·조 성할 수 없는 지역은 다음과 같다. 첫째, 「국토의 계획 및 이용 에 관한 법률」에 따른 녹지지역 중 대통령령으로 정하는 지역, 둘째, r수도법」에 따른 상수원보호구역, 셋째, r문화재보호법,에 따른 보호구역, 넷째, 그밖에 대통령령으로 정하는 지역히이며, 이 외에도 ${ }^{\top}$ 자연공원법」, ${ }^{\top}$ 자연환경보전법」에 따라 자연공원, 생 태자연도 1 등급 지역도 묘지 등의 설치가 제한된다(Moon and Lee, 2018).

산림복지서비스 중 수목장(樹木葬)은 기존의 장법이 갖는 여 러 문제들을 해결할 수 있는 좋은 장례방법이다(Woo, 2013). 매장에서 화장으로 장사문화가 변화(Ministry of Health and Welfare(2007); Ministry of Health, Welfare and Family Affairs 
(2009))하고 있으며, 선행연구를 통해 국민들의 자연장 선호도 가 높고(KFS, 2014; KFS, 2015a; KFS, 2015b), 수목장림의 운영주체로는 국가 또는 공공기관을 선호하는 것을 확인할 수 있었다(Gwon, 2014).

그러나 80세 이상의 잠재이용인구를 모두 수용한다고 가정 하면 현재 운영 중인 하늘숲추모원 규모의 30 배의 수목장림이 더 조성되어야 할 것으로 예상된다(KFS, 2015a).

수목장림의 입지조건을 검토한 결과, 장사 등에 관한 법률과 다른 법률에 따라 조성이 불가능한 법적인 제한지역이 다수 존 재함을 확인하였다(Moon and Lee, 2018). 그러나 현행 장사 등에 관한 법률에 따른 조성기준에는 면적, 표지, 안전 등 포괄 적인 규정만 존재하고, 조성을 위한 구체적인 시설규정이 없는 상태이다(KFS, 2014).

\section{2. 산림복지시설 및 기타 시설의 입지}

산림복지시설이란 산림복지서비스를 제공하기 위하여 조성 된 시설로서 자연휴양림, 산림욕장, 치유의 숲, 숲길, 유아숲체 험원, 산림교육센터, 숲속야영장, 산림레포츠시설 그리고 수목 장림(樹木葬林) 등이 있다.

산림복지시설의 입지 선정과 관련해서는 Kim et al.(2003), Lim(2008), Jo(2010), Kim et al.(2010), KFS(2011), Park(2013) 등의 연구가 진행되었으며, 자연휴양림 등 산림복지시설을 지정 또는 조성하고자 할 때에는 산림청고시 세부기준에 따라 타당성 평가를 실시하여야 하며, 평가점수의 합이 총점 대비 $66.6 \%$ 이상인 경우에 한하여 지정 또는 조성 대상에 포함한다 (Moon and Lee, 2018).

산림복지시설 외에 기타 시설의 입지와 관련한 연구는 Lee (1998), Yoon(2006), Ministry of Environment(2007)의 폐기물 처리시설, Ministry of Patriots and Veterans Affairs(2007)의 국립호국원(국립묘지), Park and Song(2010), Jeong(2017)의 물류시설, Nam and Lim(2011), Kim(2012b), Lee(2018), Choi (2018) 등의 관광 - 체육시설, Hong and Park(2003), Choi(2016) 의 도시 · 농촌공공시설과 군사시설 입지에 대한 Lee(2013) 등 의 연구가 있으며, 이들 선행연구에서 적정입지 선정을 위해 $\mathrm{AHP}$ 분석을 실시하거나, GIS를 활용하고 있음을 확인할 수 있었다.

자연휴양림 등 수목장림 외에 다른 산림복지시설의 경우, 예 정지의 적지판정기준을 마련하기 위한 선행연구를 토대로 법 제화 되어 지정 또는 조성계획승인 등의 절차에 앞서 타당성 평가를 통해 입지선정과정의 신뢰성을 높이고 있으나, 수목장 림은 입지에 대한 타당성 평가 등의 제도는 마련되어 있지 않 았다.

산림복지시설뿐만 아니라, 물류시설, 관광체육시설, 소각장 등 다수의 사례에서 적정입지 선정을 위해 다양한 요소를 고려하
고, 전문가의 의견을 종합하는 등 종합적인 분석수단으로 계층 분석방법 $(\mathrm{AHP})$ 을 적극 활용하고 있었다.

\section{3. 평가요인 도출}

산림복지시설인 수목장림의 입지와 관련이 있는 선행연구 및 관련 법령과 규정에 대한 고찰을 통해서 예비평가요인을 도출하기 위해 산림복지시설의 지정, 조성계획 승인, 등록 등의 절차(Moon et al., 2018)와 유사한 산림시설인 수목원과 생태 숲의 조성과정과 평가인자를 확인하였으며, 국립수목장림인 하늘숲추모원의 이용자 만족도 조사결과(FOWI, 2017)를 토대 로 도출한 이용자의 고려요소 및 기타 시설 입지와 관련한 선 행연구를 통해 도출한 평가인자를 고려하였다.

선행연구 등을 토대로 도출한 수목장림 적지평가를 위한 예 비평가요인은 총 266개 요인으로 나타났다(Table 1 참조). 이 중에서 유사한 의미나 이름 등 중복 요인 119 개와 개별 사업만 이 갖는 특수한 요인이거나, 평가방법이 모호한 요인 73개를 제외하여 총 74 개의 예비평가요인을 도출하였고 평가요인 선 정을 위한 재분류에 앞서 전문가 의견을 수렴하는 예비조사 ${ }^{4}$ 를 실시하였다.

Table 1. Evaluation factors of literature review

\begin{tabular}{|c|c|c|c|}
\hline \multirow{2}{*}{ Types } & \multicolumn{2}{|c|}{ Evaluation } & \multirow{2}{*}{ Sources } \\
\hline & Division & Item & \\
\hline Natural recreation forest & 5 & 30 & \multirow{5}{*}{$\begin{array}{c}\operatorname{KFS}(2016) \\
\text { Moon et al.(2018); } \\
\text { Moon and Lee(2018). }\end{array}$} \\
\hline Healing forest & 6 & 33 & \\
\hline A forest bath & 5 & 15 & \\
\hline A forest camp & 4 & 15 & \\
\hline Forest reports facility & 4 & 15 & \\
\hline $\begin{array}{l}\text { Forest visitor center } \\
\text { for little children }\end{array}$ & 3 & 12 & \multirow{2}{*}{$\begin{array}{l}\text { Forest Education } \\
\text { Promotion Act }\end{array}$} \\
\hline Forest education center & 4 & 20 & \\
\hline Woodland burial ground & 6 & 26 & $\operatorname{KFS}(2012)$ \\
\hline National arboretums & 3 & 8 & $\begin{array}{l}\text { Act on the creation and } \\
\text { furtherance of } \\
\text { arboretums and gardens }\end{array}$ \\
\hline Ecological woods & 3 & 15 & Forest Protection Act \\
\hline $\begin{array}{l}\text { National woodland burial } \\
\text { ground resource user survey }\end{array}$ & - & 4 & FOWI(2017) \\
\hline Waste incinerator & - & 12 & Lee(1998) \\
\hline Natual burials & - & 11 & $\begin{array}{l}\text { Ministry of Patriots and } \\
\text { Veterans affairs (2007) }\end{array}$ \\
\hline Logistics complex & - & 5 & Park and Song(2010) \\
\hline MICE & - & 20 & Nam et al.(2011) \\
\hline Railway logistics depots & - & 9 & Jeong (2017) \\
\hline Golf course & - & 16 & Choi (2018) \\
\hline Total & & 266 & \\
\hline
\end{tabular}


예비 평가요인이 갖는 특성에 따라 산림환경과 인문환경으 로 대분류하고, 산림환경은 다시 산림경관, 산림자원, 휴양유발 로 구분하고, 인문환경은 지리조건, 개발여건, 운영관리 항목으 로 구분하여 각각의 중분류 특성에 맞는 예비평가요인을 세분 하였으며, 항목별 평가요인을 선정하기 위해 전문가들이 예비 요인 평가에서 $1 / 2(50.0 \%)$ 이상 선택한 요인을 파악하여 대분 류 2 개 항목, 중분류 6 개 항목, 소분류 22 개 항목을 이번 연구 에서 사용할 평가요인으로 선정하였다.

\section{III. 연구방법}

「장사 등에 관한 법률」제 16 조(자연장지의 조성)에 따라 수 목장림을 조성할 수 있는 주체는 국가, 시 · 도지사 또는 시장 군수 구청장, 개인 - 가족, 종중 - 문중, 법인 - 종교단체, 자연장 지의 조성 - 관리를 목적으로 「민법」에 따라 설립된 재단법인 등이 있으나(Moon and Lee, 2018), 이 연구에서는 이용자 선 호도가 높은 국가나 공공기관이 수목장림을 운영하는 것을 가 정하여 국립수목장림을 연구의 범위로 설정하였다.

연구의 체계는 다음과 같다. 수목장림 입지 설정을 위한 평 가기준 마련을 위해 선행연구를 고찰하여 예비 평가요인을 도 출하고, 전문가 검토를 통해 평가요인을 선정한다. 선정된 평가 요인은 전문가 선호도 조사를 통해 평가요인별 중요도를 분석 하여 평가요인을 수목장림 후보지에 적용할 수 있도록 평가 기 준표를 마련한다. 이렇게 마련된 평가기준표를 활용해 선행연 구(KFS, 2015b)에서 수목장림 후보지로 평가하였던 후보지에 적용해 선행연구의 평가결과와 비교해 연구의 시사점을 도출 한다.

\section{1. 평가요인에 대한 중요도 분석}

선행연구 검토를 통해 산림복지시설과 유사한 산림시설, 기 타 시설의 입지선정과정에서의 검토요소를 분석하여 예비평가 요인을 선정하였고, 이를 토대로 3그룹의 전문가집단을 대상으 로 예비평가요인에 대한 검토를 거쳐 평가요인을 선정하였다. 분야별 요인의 수치화된 중요도 산정을 위해 각 속성의 평가 요소들을 계층화하고, 계층별 요소들에 대한 쌍대비교를 통해 $\mathrm{AHP}$ 분석을 실시해 중요도를 분석하였다.

선행연구 고찰을 통해 설정한 74 개 예비평가요인에 대한 전 문가 의견조사를 토대로 예비 평가요인이 갖는 특성에 따라 산 림환경과 인문환경으로 대분류하고, 산림환경은 다시 산림경관, 산림자원, 휴양유발로 구분하고, 인문환경은 지리조건, 개발여 건, 운영관리 항목으로 구분하여 각각의 중분류 특성에 맞는 예비평가요인을 세분하여 분류하였다.

예비조사에서 오류 없이 회수된 의견을 제시한 전문가를 대 상으로 진행된 2차 조삳ㄱ결과를 연구에 사용하였다. 평가요인
에 대한 쌍대비교를 통해 정성적인 선호 정도를 계량화하기 위해 신뢰할 만한 평가척도로 Saaty가 제안한 1 9점 척도 를 활용하였고, 응답이 일관되게 평가되었는지를 검증하기 위 해 일관성지수(Consistency Index: CI)를 임의지수(Random Index: RI)로 나누어 산정한 일관성비율(Consistency Ratio: $\mathrm{CR)}$ 을 산정하고, $10 \%$ 이내일 경우 평가자가 내린 평가항목들 에 대한 판단은 일관성이 있다(Jeong, 2017)고 보았다.

\section{2. 수목장림 입지평가 기준 설정}

선행연구 고찰과 전문가 검토를 거쳐 선정된 평가요인을 토 대로 수목장림의 입지평가 기준을 설정한다.

산림복지시설 예정지에 대한 타당성 평가에 적용되는 평가 표를 참고하여 연구에서 도출한 수목장림 적지평가 기준의 세 부평가인자별로 1점에서 5점 중 임의의 점수를 주는 형태로 평 가서를 작성하여 수목장림 적지평가 기준표를 마련한다.

설정한 평가기준에 의한 수목장림 예정지 적지평가 기준표는 객관성 및 일선 현장에서의 업무효율성 등을 고려하여 현행 산림청고시 제2018-71호 “자연휴양림 등 타당성 평가의 세부 기준”과 동일한 기준인 평가점수의 합이 총점 대비 $66.6 \%(2 / 3)$ 이상인 경우에 한하여 적지로 판정하는 것으로 적용하였다.

\section{3. 평가기준에 따른 입지 분석 및 평가}

입지평가기준을 사례에 적용하기 위해 $\mathrm{KFS}(2015 \mathrm{~b})$ 의 선행 연구에서 국립수목장림 후보지로 검토하였던 9개소와 운영 중 인 국립수목장림인 하늘숲추모원을 대상으로 평가하고, 가중치 를 적용하여 각 후보지별 평가결과를 도출하였다.

후보지에 대한 세부 평가에 활용하는 자료는 한국임업진흥 원의 필지별 산림정보(https://gis.kofpi.or.kr), 국토교통부의 토지이용규제정보서비스(http://luris.molit.go.kr) 등 가급적 공개된 자료를 활용하여 현장적용에 용이토록 하였으나, 실제 평가 시와 달리 이번 연구에서는 선행연구의 대상지를 가상의 후보지로 설정하여 평가하므로, 기존자료 및 원격분석을 통해 평가가 가능한 산림환경부분만 평가하였다.

적지평가기준을 사례에 적용하기 위해 선행연구에서 국립수 목장림 후보지로 검토하였던 9개소와 현재 운영 중인 국립수 목장림인 하늘숲추모원을 대상으로 평가하였고, 평가 요소에 적용된 가중치를 적용하여 각 후보지별 평가결과에 대한 고찰 을 통해 연구의 시사점을 도출하였다.

\section{IV. 결과 및 고찰}

\section{1. 평가요인에 대한 중요도 분석}

선행연구 고찰을 통해 설정한 74 개 예비평가요인에 대한 전 
문가 의견조사를 토대로 선정된 평가요인을 계층화하여 산림 환경과 인문환경으로 대분류하고, 이를 각각 3 가지 항목으로 계층화하여 중분류한 뒤, 다시 각각의 소분류항목으로 계층화 하여 중요도 차이를 확인한 결과, 대분류 항목에서는 산림환경 (0.637)이 인문환경 $(0.363)$ 보다 중요도가 높게 평가되었고, 산림 환경에서는 산림자원(0.461), 산림경관(0.314), 휴양유발(0.225), 인문환경에서는 개발여건(0.467), 운영관리(0.309), 지리조건 (0.224)의 순으로 중요하게 평가되었다. 산림경관에서는 수목 의 생육상태(0.577), 산림자원에서는 추모목 훼손 우려(0.325), 휴양유발에서는 대상지 내 환경파괴 정도( 0.715$)$, 지리조건에서 는 대중교통 편의성(0.547), 개발여건에서는 관련계획 및 법규 (0.310), 운영관리에서는 사업계획의 구체성 $(0.239)$ 이 각각 가 장 중요하게 평가되었다. 소분류 평가항목 중 추모목 생육상태 가 가장 높았으며, 다음으로 대상지내 환경파괴 정도 추모목 훼 손 우려 등의 순으로 나타났다(Table 2 참조).

종합 중요도 분석에서 수목의 생육상태 항목이 가장 높게 나 타난 것은 산림복지시설인 수목장림 입지선정을 위해 산림환 경 중 산림경관을 구성하는 수목의 생육상태가 중요하며, 그 외에도 대상지내 환경파괴 정도, 추모목 훼손 우려, 산림식물의 종 다양성 등 산림환경에 해당하는 평가요인이 높은 중요도로
평가되었음을 확인할 수 있었다.

\section{2. 수목장림 입지평가 기준 설정}

산림복지시설인 수목장림 입지설정을 위해 선행연구 고찰과 전문가 검토를 통해 마련된 평가요인을 토대로 선정된 "산림 경관", “산림자원”, “휴양유발”, "지리조건”, "개발여건”, “운영 관리" 등 6 개 항목 22 개 요인별 평가기준을 설정하기 위해 산 지구분타당성 조사 및 산지구분조정 지침, 수목장림 조성 및 운영 - 관리 편람(KFS, 2012), 자연휴양림 등 타당성 평가 세부 기준(KFS, 2018) 등을 참고하여 각 평가요인의 특성에 맞은 기준을 설정하였다(Table 3 참조)

설정한 평가기준에 의한 수목장림 예정지 적지평가 기준표 는 객관성 및 일선 현장에서의 업무효율성 등을 고려하여 현행 “자연휴양림 등 타당성 평가의 세부기준”과 동일한 기준인 평 가점수의 합이 총점 대비 $66.6 \%(2 / 3)$ 이상인 경우에 한하여 적지로 판정하는 것으로 적용하였다.

\section{3. 평가기준에 따른 입지 분석 및 평가}

이번 연구에서 설정한 입지평가기준을 활용하여 기존에 운

Table 2. Results of importance analysis by factor

\begin{tabular}{|c|c|c|c|c|c|c|c|c|c|}
\hline \multicolumn{2}{|c|}{ Categories } & \multicolumn{2}{|c|}{ Sub-categories } & \multicolumn{2}{|l|}{ Segments } & \multirow{2}{*}{ Rank } & \multirow{2}{*}{$\mathrm{CR}$} & \multicolumn{2}{|c|}{ Total } \\
\hline Division & Importance & Division & Importance & Division & Importance & & & Importance & Rank \\
\hline \multirow{9}{*}{$\begin{array}{c}\text { Forest } \\
\text { environment }\end{array}$} & \multirow{9}{*}{0.637} & \multirow{3}{*}{$\begin{array}{c}\text { Forest } \\
\text { landscape }\end{array}$} & \multirow{3}{*}{0.314} & The angle of slope & 0.320 & 2 & \multirow{3}{*}{0.160} & 0.064 & 5 \\
\hline & & & & Degree of closure & 0.577 & 1 & & 0.115 & 1 \\
\hline & & & & Above sea level & 0.103 & 3 & & 0.021 & 18 \\
\hline & & \multirow{4}{*}{$\begin{array}{l}\text { Forest } \\
\text { resources }\end{array}$} & \multirow{4}{*}{0.461} & Soil type(quality) & 0.148 & 4 & \multirow{4}{*}{0.719} & 0.043 & 10 \\
\hline & & & & The number of memory trees per 'ha' & 0.208 & 3 & & 0.061 & 6 \\
\hline & & & & The variety of forest plants & 0.320 & 2 & & 0.094 & 4 \\
\hline & & & & Fear of damaging the memory trees & 0.325 & 1 & & 0.095 & 3 \\
\hline & & \multirow{2}{*}{$\begin{array}{l}\text { Recreational } \\
\text { induction }\end{array}$} & \multirow{2}{*}{0.225} & Linkage of recreation forest facilities & 0.285 & 2 & \multirow{2}{*}{0.000} & 0.041 & 11 \\
\hline & & & & Environmental destruction in target site & 0.715 & 1 & & 0.102 & 2 \\
\hline \multirow{13}{*}{$\begin{array}{c}\text { Human } \\
\text { environment }\end{array}$} & \multirow{13}{*}{0.363} & \multirow{3}{*}{$\begin{array}{l}\text { Geography } \\
\text { condition }\end{array}$} & \multirow{3}{*}{0.224} & Convenience of public transport & 0.547 & 1 & \multirow{3}{*}{1.663} & 0.044 & 9 \\
\hline & & & & Direction & 0.138 & 3 & & 0.011 & 20 \\
\hline & & & & Distance between neighboring cities & 0.315 & 2 & & 0.026 & 15 \\
\hline & & \multirow{4}{*}{$\begin{array}{l}\text { Development } \\
\text { condition }\end{array}$} & \multirow{4}{*}{0.467} & Topography for facility entry & 0.180 & 4 & \multirow{4}{*}{0.839} & 0.031 & 13 \\
\hline & & & & Related plans and regulations & 0.310 & 1 & & 0.053 & 7 \\
\hline & & & & Preference of local residents & 0.281 & 2 & & 0.048 & 8 \\
\hline & & & & Local government cooperation & 0.229 & 3 & & 0.039 & 12 \\
\hline & & \multirow{6}{*}{$\begin{array}{c}\text { Operation } \\
\text { management }\end{array}$} & \multirow{6}{*}{0.309} & The adequacy of the management plan & 0.218 & 2 & \multirow{6}{*}{1.589} & 0.024 & 16 \\
\hline & & & & Management personnel expertise & 0.162 & 4 & & 0.018 & 19 \\
\hline & & & & The concreteness of the project plan & 0.239 & 1 & & 0.027 & 14 \\
\hline & & & & Reliability of the operating entity & 0.201 & 3 & & 0.023 & 17 \\
\hline & & & & Parking lot & 0.096 & 5 & & 0.011 & 21 \\
\hline & & & & Fire fighting facilities & 0.085 & 6 & & 0.010 & 22 \\
\hline
\end{tabular}


Table 3 Site evaluation criteria for woodland burial grounds

\begin{tabular}{|c|c|c|c|c|c|c|}
\hline \multirow{2}{*}{ Categories } & \multicolumn{5}{|c|}{ Site evaluation criteria (Point) } & \multirow{2}{*}{ Weight } \\
\hline & 1 & 2 & 3 & 4 & 5 & \\
\hline \multicolumn{7}{|c|}{ 1. Forest landscape } \\
\hline The angle of slope & More $30^{\circ}$ & $25^{\circ} \sim 30^{\circ}$ & $20^{\circ} \sim 25^{\circ}$ & $15^{\circ} \sim 20^{\circ}$ & Under $15^{\circ}$ & 0.064 \\
\hline Degree of closure & Under $40 \%$ & - & $40 \sim 70 \%$ & - & More $70 \%$ & 0.115 \\
\hline Above sea level & More $500 \mathrm{~m}$ & - & $400 \sim 500 \mathrm{~m}$ & - & Under $400 \mathrm{~m}$ & 0.021 \\
\hline \multicolumn{7}{|c|}{ 2. Forest resources } \\
\hline \multirow{2}{*}{ Soil type(quality) } & \multicolumn{5}{|c|}{ Sandy loam, Loam } & \multirow{2}{*}{0.043} \\
\hline & Under $50 \%$ & - & $50 \sim 80 \%$ & - & Over $80 \%$ & \\
\hline The number of memory trees per 'ha' & Under 100 & - & $100 \sim 200$ & - & Over 200 & 0.061 \\
\hline The variety of forest plants & Under 3 & - & $3 \sim 6$ & - & Over 6 & 0.094 \\
\hline Fear of damaging the memory trees & High & - & Normal & - & Low & 0.095 \\
\hline \multicolumn{7}{|c|}{ 3. Recreational induction } \\
\hline Linkage of recreation forest facilities & None & - & $1 \sim 2$ & - & $3 \sim 4$ & 0.041 \\
\hline Environmental destruction in target site & Worst & Bad & Normal & Good & Best & 0.102 \\
\hline \multicolumn{7}{|c|}{ 4. Geography condition } \\
\hline Convenience of public transport & None & - & Normal & - & High & 0.044 \\
\hline Direction & $\begin{array}{l}\text { S, SW, SE } \\
\text { under } 50 \%\end{array}$ & - & $\begin{array}{l}\text { S, SW, SE } \\
50 \% \sim 80 \%\end{array}$ & - & $\begin{array}{l}\text { S, SW, SE } \\
\text { over } 80 \%\end{array}$ & 0.011 \\
\hline Distance between neighboring cities & Over index 5 & Index $4 \sim 5$ & Index $3 \sim 4$ & Index $2 \sim 3$ & Under index 2 & 0.026 \\
\hline \multicolumn{7}{|c|}{ 5. Development condition } \\
\hline \multirow{2}{*}{ Topography for facility entry } & \multicolumn{5}{|c|}{ Minimum area of designated forest } & \multirow{2}{*}{0.031} \\
\hline & Under $1 \%$ & Under $2 \%$ & Under $3 \%$ & Under $5 \%$ & Over $5 \%$ & \\
\hline Related plans and regulations & Very High & High & Normal & Low & None & 0.053 \\
\hline Preference of local residents & Low & - & Normal & - & High & 0.048 \\
\hline Local government cooperation & Low & - & Normal & - & High & 0.039 \\
\hline \multicolumn{7}{|c|}{ 6. Operation management } \\
\hline The adequacy of the management plan & Low & - & Normal & - & High & 0.024 \\
\hline Management personnel expertise & Low & - & Some experts & - & Field experts & 0.018 \\
\hline The concreteness of the project plan & Low & - & Normal & - & High & 0.027 \\
\hline Reliability of the operating entity & Individual & - & The artificial person & - & $\begin{array}{c}\text { The state, local } \\
\text { government, public } \\
\text { institutions }\end{array}$ & 0.023 \\
\hline Parking lot & None & $\begin{array}{l}\text { Purchase } \\
\text { possibility }\end{array}$ & $\begin{array}{c}\text { Possibility } \\
\text { (small scale) }\end{array}$ & $\begin{array}{l}\text { Possibility } \\
\text { (big scale) }\end{array}$ & $\begin{array}{l}\text { Existing parking } \\
\text { available }\end{array}$ & 0.011 \\
\hline Fire fighting facilities & $\begin{array}{c}\text { Fire truck } \\
\text { unable to enter }\end{array}$ & $\begin{array}{l}\text { Small fire truck } \\
\text { unable to enter }\end{array}$ & $\begin{array}{c}\text { Possibility } \\
\text { (small scale) }\end{array}$ & $\begin{array}{l}\text { Possibility } \\
\text { (big scale) }\end{array}$ & $\begin{array}{l}\text { Existing fire fighting } \\
\text { facilities available }\end{array}$ & 0.010 \\
\hline
\end{tabular}

영되고 있는 국립수목장림과 선행연구에서 국립수목장림 후보 지로 검토하였던 9 개소를 대상으로 사례를 비교 평가하였다.

설정된 6 개 소분류 22 개 평가항목의 입지평가기준을 10 개 비교 대상지에 적용하여 평가표를 작성하고, 평가 결과에 종합 가중치를 적용하였다.

실제 평가 시와 달리 이번 연구에서는 선행연구의 대상지를 가상의 후보지로 설정하여 평가하므로 기존자료 및 원격분석 을 통해 평가가 가능한 산림환경부분만 평가하였고, 평가 결 과에 가중치를 적용한 결과, 울산 울주 지역이 59.09점으로 가 장 높게 평가되었으며, 전남 순천, 세종 장군, 강원 평창, 강원 삼척, 충남 보령, 하늘숲추모원의 순으로 평가되었다(Table 4
참조).

적지판정의 기준으로 설정한 22 개 항목(110점)의 2/3(66.6\%) 인 73.26점과 산림환경부분의 만점이 69.96 점임을 고려하면 $2 / 3$ 기준인 46.59 점 이상인 7개소가 산림환경이 우수한 것으로 분석되었다.

\section{4. 고찰}

10 개 비교대상지를 대상으로 가중치를 적용한 평가결과에 대한 고찰을 통해 도출한 시사점은 다음과 같다.

수목장림 조성 및 운영관리편람(KFS, 2012)에서는 수목장 
Table. 4 Review assessment of the site location and limited area analysis

\begin{tabular}{|c|c|c|c|c|c|c|c|}
\hline \multirow{2}{*}{ No } & \multirow{2}{*}{ Site location } & \multicolumn{3}{|c|}{ Literature review(KFS, 2015b) } & \multirow{2}{*}{ Result } & \multicolumn{2}{|c|}{ Limited area analysis } \\
\hline & & Point & Grade & Result & & Limiting factor & Result \\
\hline 1 & National Hanulsoop Forest Memorial Park & - & - & - & 48.44 & - & - \\
\hline 2 & Janggun-myeon, Sejeong City & 77 & 2 & Appropriate & 56.72 & - & - \\
\hline 3 & Muju County, Jeollabuk-do & 68 & 3 & Inappropriate & 45.80 & - & - \\
\hline 4 & Ulju County, Ulsan City & 54 & 4 & Inappropriate & 59.09 & 1 & Inappropriate \\
\hline 5 & Samcheok City, Gangwon-do & 61 & 3 & Inappropriate & 49.81 & - & - \\
\hline 6 & Pyeongchang County, Gangwon-do & 76 & 2 & Appropriate & 54.43 & 2 & Inappropriate \\
\hline 7 & Hoengseong County, Gangwon-do & 41 & Exclude & Inappropriate & 46.18 & 3 & Inappropriate \\
\hline 8 & Hongcheon County, Gangwon-do & 55 & 4 & Appropriate & 44.88 & 3 & Inappropriate \\
\hline 9 & Suncheon City, Jeollanam-do & 66 & 3 & Inappropriate & 57.64 & 2 & Inappropriate \\
\hline 10 & Boryeong City, Chungcheongnam-Do & 70 & 2 & Appropriate & 48.62 & - & - \\
\hline
\end{tabular}

림 대상지 선정 평가표에 따라 평가점수가 80점 이상인 경우 1 급지, 70 점 이상 80 점 미만인 경우 2급지, 60점 이상 70점 미만 인 경우 3 급지, 50 점 이상 60 점 미만인 경우 4급지로 판정하고, 평가점수 50점 미만인 경우 대상지에서 제외토록 정하고 있고, 선행연구에서는 9 개 후보지에 대해 위 기준을 적용한 등급 판 정이후 연구진의 종합 판단에 따라 적격 여부를 명시하여 3 급 지를 부적격으로 판정하거나 4 급지를 적격으로 판정하는 사례 도 있었다.

연구자는 평가 기준표에 따른 분석 외에 연구결과의 고찰을 위해 연구대상지 10 개소를 대상으로 「장사 등에 관한 법률」, '자 연공원법」, 「자연환경보전법, 등에 따라 수목장림의 설치가 제 한되는 지역 여부를 확인하기 위해 Moon and Lee(2018)의 연 구방법을 활용하여 법적 제한지를 분석하였다.

분석결과 5 개소의 경우, 법적 설치제한지에 입지하고 있어 수목장림 설치가 불가능한 것으로 분석되었다.

강원 평창군과 강원 홍천군의 경우, 선행연구에서는 적격으 로 판정하였으나, 법적 제한지 여부를 분석한 결과, 부적격지로 확인되었다. 평창의 경우, 선행연구와 연구자의 평가 모두 높게 평가되었고, 울산 울주 및 전남 순천 등도 산림환경은 높게 평 가되었으나, 상수원보호구역 등 법적 제한지에 입지하고 있어 실제 사업추진은 어려울 것으로 분석되었다(Table 4 참조).

따라서 산림이 갖는 산림환경과 인문환경에 대한 평가 이전 에 이처럼 법적 제한지역에 해당하는지 여부를 확인하는 등 필 수 확인사항에 대한 검토가 선결되어야 할 것이다.

\section{V. 결론}

국민의 산림복지에 대한 수요가 증가하고, 생애주기와 밀착 한 다양한 산림복지시설에 대한 요구가 제기되고 있으며, 그 중에서도 생애주기 중 회년기에 해당하는 산림복지시설인 수 목장림은 늘어나는 수요에 비해 공급이 매우 부족한 실정이다.
수목장림의 입지 선정을 위한 평가요소를 마련하고, 가중치 적용을 통해 수목장림 조성에 도움이 되는 입지 평가기준을 제 시하고자 다음과 같이 연구를 진행하였다.

선행연구 검토를 통해 다른 산림복지시설과 유사한 산림시 설, 기타 시설들의 입지선정과정에서의 검토요소를 분석하여 74 개의 예비평가요인을 선정하였고, 이를 토대로 전문가집단의 예비평가요인에 대한 검토를 거쳐 2 개 대분류, 6 개 중분류, 22 개 소분류의 평가요인을 선정하였다. 선정한 평가요인은 전문가 선호도 조사를 위해 평가인자를 산림환경과 인문환경으로 대 분류하고, 이를 각각 3 가지 항목으로 중분류한 뒤 다시 각각의 소분류항목으로 계층화하였다.

계층화된 각 요인에 대한 쌍대비교를 통해 전문가 선호도를 분석하고, AHP 분석을 통해 요인별 중요도 차이를 확인하였다.

대분류, 중분류, 소분류의 각 계층별 중요도를 반영한 종합 중요도 분석 결과, 수목의 생육상태(0.115)가 가장 높았으며, 다 음으로 대상지내 환경파괴정도(0.102), 추모목 훼손우려(0.095) 등의 순으로 분석되는 등 산림환경에 해당하는 평가요인이 높 게 평가되었음을 확인할 수 있었다.

평가요인을 활용하여 입지평가 기준표를 작성하고, 이를 후 보지에 적용하기 위해 선행연구에서 국립수목장림 후보지로 검토하였던 9 개소와 기존에 운영하고 있는 국립수목장림인 하 늘숲추모원 등 10 개소를 대상으로 평가하여 비교 분석하였다.

분석 결과는 다음과 같다.

실제 평가 시와 달리 이번 연구에서는 선행연구의 대상지를 가상의 후보지로 설정하여 평가하므로 기존자료 및 원격분석 을 통해 평가가 가능한 산림환경부분만 평가하였고, 평가 결과 에 가중치를 적용한 결과, 울산 울주 지역이 59.09점으로 가장 높게 평가되었으며, 전남 순천, 세종 장군, 강원 평창, 강원 삼 척, 충남 보령, 하늘숲추모원의 순으로 평가되었다.

적지판정의 기준으로 설정한 22 개 항목(110점)의 $2 / 3$ 인 73.26 점과 산림환경부분의 만점이 69.96 점임을 고려하면 $2 / 3(66.6 \%)$ 
기준인 46.59점 이상인 7개소가 산림환경이 우수한 것으로 분 석되었다.

수목장림 조성 및 운영관리편람에서는 수목장림 대상지 선 정 평가표에 따라 평가점수가 80점 이상인 경우 1급지, 70 점 이 상 80점 미만인 경우 2급지, 60점 이상 70 점 미만인 경우 3 급 지, 50 점 이상 60 점 미만인 경우 4 급지로 판정하고, 평가점수 50점 미만인 경우 대상지에서 제외토록 정하고 있다.

선행연구에서는 9 개 후보지에 대해 위 기준을 적용한 등급 판정이후 연구진의 종합 판단에 따라 적격 여부를 명시하여 3 급지를 부적격으로 판정하거나, 4 급지를 적격으로 판정하는 사 례도 있었다.

연구자는 평가 기준표에 따른 산림환경부분의 분석 외에 연 구결과의 고찰을 위해 하늘숲추모원을 포함한 연구대상지 10 개소를 대상으로 '장사 등에 관한 법률」, '자연공원법」, '자연 환경보전법, 등에 따라 수목장림의 설치가 제한되는 지역 여부 를 확인하기 위해 법적 제한지를 분석하였다. 분석결과, 5 개소 가 법적 설치제한지에 입지하고 있어 수목장림 설치가 불가능한 것으로 분석되었다. 강원 평창과 홍천의 경우, 선행연구에서는 적격으로 판정하였으나, 법적 제한지의 분석 결과, 부적격지로 확인되었다. 평창의 경우, 선행연구와 연구자의 평가 모두 높게 평가되었고, 울산 울주 및 전남 순천 등도 산림환경은 높게 평 가되었으나, 상수원보호구역 등 법적 제한지에 입지하고 있어 실제 사업추진은 어려울 것으로 분석되었다. 따라서 수목장림 후보지에 대한 평가 이전에 법적 제한지역에 해당하는지 확인 하는 등 필수 확인사항에 대한 검토가 선결되어야 할 것이다.

이러한 연구의 결과는 국립수목장림 조성을 위한 타당성 평 가 등의 제도 보완을 통해 실무 적용을 검토할 수 있을 것이다.

이번 연구는 산림복지시설인 수목장림의 입지 설정과정에 필 요한 항목을 도출하고, 이를 토대로 입지결정과정에서의 객관 적이고 정량적인 평가를 통해 의사결정을 할 수 있도록 평가기 준을 마련하여 제시하고자 하였다. 그러나 다음과 같은 한계가 있음을 밝혀둔다.

첫째, 예비요인의 검토를 통해 평가요인을 선정하기 위해 전 문가의 의견을 수렴하였으나, 선호도 조사에서 전문가들의 주 관적인 요소가 개입될 수 있는 한계가 있다.

둘째, 객관적인 평가기준을 토대로 후보지에 대한 입지기준 을 마련코자 하였으나, 실제 추진과정에서 지역주민 등 이해관 계자의 주관적인 선호도에 따라 의견에 차이가 있을 수 있다.

셋째, 평가기준뿐만 아니라, 수목장림 운영관리편람 등 관 련연구가 진행되기 이전에 조성된 수목장림의 경우 이번 평가 기준에 따른 입지결정과 부합하지 못할 수 있는 한계가 있다.

이러한 연구의 한계점이 존재하지만, 이번 연구는 다른 산림 복지시설의 경우처럼 수목장림의 조성과정에 적용할 수 있는 적지평가 기준을 제시하였다는데 그 의미가 있다고 판단된다. 또한 수목장림의 입지선정을 위해 죽은자와 산자가 만나는
공간인 수목장림이 갖는 장소성, 우리의 풍수지리와 경관, 지명 이나 장소가 갖는 이야기 등 정성적 개념의 측면 역시 입지선 정과정에서 매우 중요한 고려요소이나, 이번 연구에서는 정량 적으로 분석 가능한 부분에 대한 평가에 집중하여 정성적 측면 에 대한 논의가 필요하며, 이번 연구의 한계점을 고려하여 입 지평가기준에 대한 신뢰성을 높이고, 현장에 적용하기 위한 제 도개선과 사유림에 적용 가능한 적지평가기준 마련 등 후속연 구가 지속적으로 이뤄져야 할 것이다.

주 1. 2013 수목장에 대한 국민의식조사」결과를 통해 도출된 60 대 이상 의 수목장 선호인구 $4,194,074$ 명 중 80 세 이상의 잠재이용인구는 572,303 명으로 이들을 $100 \%$ 수용할 경우 수목장림은 하늘숲추모원 규모 기준 45 개소가 필요하고, 수목장림의 면적은 $2,160 \mathrm{ha}$ 로 현재 조 성면적의 30 배가 더 조성되어야 할 것으로 예측됨(KFS, 2015a).

주 2. 「산림문화 - 휴양에 관한 법률」 제 21 조의 2 (자연휴양림 등의 타당성 평가)에 따라 시행하는 대상지의 경관·위치·면적 등이 대통령령 으로 정한 기준에 적합한지에 대한 평가.

주 3. 주거지역 · 상업지역 및 공업지역, 수변구역(한강, 낙동강, 금강, 영산 강 - 섬진강 수계) 또는 특별대책지역, 접도구역, 하천구역, 농업진흥 구역, 산림보호구역, 채종림, 시험림, 특별산림보호구역, 보전국유림, 백두대간보호지역, 사방지, 군사기지 및 군사시설보호구역, 군사보호 구역, 붕괴·침수 등 보건위생상 위해를 끼칠 우려가 있는 지역으로 지자체 조례로 정하는 지역.

주 4. 2018년 5월 3 4일 모바일과 온라인 설문으로 진행하였으며, 전문가 집단은 3 개로 구성(국가 또는 공공기관 근무자(수목장림 - 산림복지 시설 업무 담당), 연구기관(산림·조경·경관·도시계획 분야의 석 사이상, 대학, 연구기관에 재직-학), 민간 전문가(수목장림 조성 운영 관련 업무 경험자))하여 조사하였고, 자연휴양림 타당성 평가 의 세부항목 등을 고려하여 예비평가요인 중 산림복지시설(수목장 림)의 입지선정을 위해 고려해야 할 중요 항목의 선택(30개)을 요청, 총 38 부가 회수되었으며, 오류가 발견된 4 부를 제외한 34 부(공공기관 7 부, 관련연구자 17 부, 민간전문가 10 부)를 연구에 활용함.

주 5. 1차 설문에 오류 없이 응답한 34인을 대상으로 2018년 5월 10 12일 모바일과 온라인 설문을 진행하였으며, 회수된 30 부(공공기관 7 부, 연구기관 15 부, 민간전문가 8 부)를 연구에 활용함.

\section{References}

1. Choi, J. Y.(2018) A Study on the Prioritization of Locational Elements of a Golf Course. Ph.D. Dissertation. Daejin University. Pocheon. Korea.

2. Choi, Y. N.(2016) Development of Evaluation Indices for Locating Public Spaces and Facilities in Rural. Ph.D. Dissertation. Kyung Hee University. Seoul. Korea.

3. Gwon, B. S. (2014) A Study on the Public Perception and Satisfaction Analysis of Tree Burials in South Korea. Master's Thesis, Kongju National University. Kongju. Korea.

4. Hong, S. E. and S. H. Park(2003) Analyzing the location of urban neighborhood parks using GIS and AHP techniques. Journal of the Korean Geographical Society 38(5): 849-860.

5. Jeong. S. K. (2017) A Study on Locational Determinants and Evaluation Model based on Railway Logistics Depots. Ph.D. Dissertation, Mokwon University. Daejeon. Korea.

6. Jo, Y. B.(2010) A Study on the Development of Suitable Locations Evaluation Model and Therapy Type to Therapeutic Forests. Ph.D. Dissertation, Wonkwang University. Iksan. Korea. 
7. Kim C. J.(2012a) A Study on the Classification of the Natural Funeral Landscape Facilities andits Visual Preference. Ph.D. Dissertation, Paichai University. Daejeon. Korea.

8. Kim, H. S., H. Y. Hwang and Y. U. Ban(2010) Evaluation model building and application for suitable locations reflecting recreation forest types. Journal of Korean Forest Society 99(1): 111-124.

9. Kim, J. J., R. H. Yoo, K. C. Sung and E. Y. Youn(2003) Criteria for assessing suitability of green shower sites. KFRI. J. For. Sci. 66: $77-93$

10. Kim. S. Y.(2012b) A Study on Prioritization of the Elements to Promote Private Investment into Tourism Development Projec. Ph.D. Dissertation, Dong-Eui University. Korea.

11. Korea Forest Service(2015a) A Basic Survey on Forest Welfare. pp. 21, pp. 143.

12. Korea Forest Service(2015b) A Study on Efficient Planning and Application Model of Woodland Burial. pp. 126-153.

13. Korea Forest Service Notice(2018) No. 71.

14. Korea Forest Service(2008) Master Plan of Forestry Culture and Recreation.

15. Korea Forest Service(2011) A Study on the Improvement of PreAuthorization Planning for Healing Forest.

16. Korea Forest Service(2012) Manual of Natural Burials Creation and Operation and Management.

17. Korea Forest Service(2014) Natural Burials Activation Plan.

18. Korea Forest Welfare Institute(2017) National Woodland Burial Ground Resource User Survey.

19. Korea Forest Welfare Institute(2018) Understanding Forest Welfare. pp. 31-33.

20. Kyon, B. H.(2011) Research on The Effective Improvement Plan of Environment Friendly Funeral Culture, with the Natual Burials as the Center. Master's Thesis, Myongi University. Seoul. Korea.

21. Lee, H. U.(2013) Positive Researchon Optimum Location Factor Decision for a Military Facility in Accordance with Changes of Governance Environment. Ph.D. Dissertation, Myongi University. Seoul. Korea.

22. Lee, K. S. (1998) Study on the waste incinerator location problem in Seoul. Journal of the Korea Regional Science Association 14(1): 91-107.

23. Lee, S. H.(2018) A Study on the Prioritization of Locational Elements of a Golf Course. Ph.D. Dissertation, Daejin University. Pocheon.
Korea.

24. Lim, Y. S.(2008) A Study on Planning Guidelines for Therpeutic Forests. Master's Thesis, Seoul National University. Korea.

25. Ministry of Environment(2007) Resource Recycle Technology of Wastes Development of Decision Support System for Landfill Siting Using Optimization and Risk Communication.

26. Ministry of Health and Welfare(2007) A Study on the Development of Natual Burials Model. pp. 100-102

27. Ministry of Health, Welfare and Family Affairs(2009) A Study on the Activation of Natural Burial Ground.

28. Ministry of Patriots and Veterans Affairs(2007) A Study on the Feasibility of the National Cemetery in Central Region.

29. Moon, C. S. and S. Y. Lee(2018) Estimation of the Availability of National Woodland Burial Ground through GIS-based Limited Area Analysis. Journal of the Korean Institute of Landscape Architecture 46(5): $36-43$

30. Moon, C. S., D. S. Kim and S. Y. Lee(2018) A study on the process of creating new forest welfare facilities. Journal East Asian Landscape Studies 12(2): 41-50

31. Nam, Y. S. and H. S. Lim(2011) A study for MCE multiplex location attributes which use AHP. Journal of The Korean Association of Professional Geographers 45(1): pp. 125-136.

32. Park, B. J., D. G. Yeom, S. B. Kim, C. W. Kyeon, D. W. Joung, G. W. Kim and Y. H. Choi (2015) A study on the characteristic analysis for the facilities of the Korea forest welfare for life cycle. Journal of Korean Society of Forest Science 104(2): 285-293

33. Park, G. C. and J. H. Song(2010) A Study on Regional Allocation Plan of Logistics Complex in Gyeonggi-do. Journal of GRI. Gyeong Research Institute.

34. Park, S. H.(2013) Study Based on Facilities for the Composition of the Forest Healing Village. Master's Thesis, Chungbuk National University. Cheongju. Korea

35. Woo, J. W.(2013) A Study on the Improvement Plan based on the Preference Factor Analysis on Tree Burial, Ph.D. Dissertation, Korea University. Seoul. pp. 1-2, pp. 61-64.

36. Yoon, Y. B. (2006) A Study on Development of an Assessment Method for Landfill Site Selection. Ph.D. Dissertation, Chonnam National University. Gwangju. Korea.

37. http://luris.molit.go.kr/web/index.jsp

38. https://gis.kofpi.or.kr/gis/mainServiceIntro/view.do \#title1
Received : 12 February, 2019

Revised : 13 May, 2019

16 May, 2019

(1st)

Accepted : 16 May, 2019

3인익명 심사필 